\author{
Klaudia Chwastek \\ http://orcid.org/0000-0002-4759-8893 \\ Akademia Ignatianum w Krakowie \\ klaudia.chwastek@gmail.com \\ DOI: $10.35765 /$ pk.2020.2902.21
}

\title{
Igersi - projekt społeczny, który stał się globalny
}

\section{STRESZCZENIE}

W artykule zostało podjęte zagadnienie związane ze społecznością igersów grupą fanów fotografii mobilnej i Instagrama, która działa na całym świecie od 2011 roku. Celem niniejszego artykułu jest ukazanie, w jaki sposób powstał ten projekt i jak jest realizowany, a także to, jaki ma wpływ zarówno na grupę, działania społeczne oraz marketingowe. W szczególności podjęta została tematyka funkcjonowania tej grupy społecznej. Podstawowym pytaniem jest to, w jaki sposób powstają lokalne społeczności igersów, mimo braku warunków do tworzenia społeczności na Instagramie. W badaniach zastosowano analizę profili i blogów prowadzonych przez grupy lokalne, których rezultatem było opisanie ich działalności zarówno w aspekcie globalnym, jak i lokalnym, a także ukazanie, że pomimo oparcia społeczności na social mediach, kontakt rzeczywisty jest równie istotny.

SŁOWA KLUCZE: igersi, instagramersi, Instagram, social media, społeczność

\section{AB STRACT}

\section{The Igers. A Social Project which Became Global}

The article deals with the Igers' community, a community of mobile photography and Instagram fans, which has been active since 2011 all over the world. The purpose of this article is to show how the project was created, how it is being realized, and how it affects both the community, its social activities and marketing. The key theme of the article is how this community works. The basic question is how this is taking place, despite the fat that you cannot create gropups on Instagram. An analysis of profiles and blogs maintained by local groups was used in the study which resulted in a description of their activities, both globally and locally, and showing that even in a community based on social media, real contact is equally important.

KEYWORD S : Igers, Instagramers, Instagram, Social Media, Community 
Celem niniejszego artykułu jest przedstawienie działalności igersów, którzy są społecznością internetową, skupioną wokół aplikacji Instagram i fotografii mobilnej. Zostanie przedstawiona i opisana geneza tego ruchu oraz analiza jego działalności na podstawie aplikacji internetowej Instagram. Wskazane zostaną przyczyny, dla których społeczność igersów wciąż prężnie się rozwija mimo trudności budowania społecznej struktury. Przede wszystkim uwaga zostanie poświęcona ogólnym założeniom grupy i opisaniu polskiej społeczności. Istotną kwestią będzie także ukazanie ich wpływu na działania społeczne oraz marketingowo-PR-owe. Społeczność ta, mimo że w tym momencie można obserwować wiele działań o podobnym charakterze, jest jedną z pierwszych tego typu, która posiada globalny zasięg, a także swoje lokalne odłamy.

Społeczność, która zostanie opisana, nazywana jest igersami, jednak w literaturze przedmiotu pojawia się pewien problem definicyjny, dlatego na wstępie przybliżona zostanie geneza nazwy tej grupy. W literaturze przedmiotu członkowie tej społeczności nazywani są igersami lub instagramersami. Nie są to jednak sformułowania tożsame. Niektórzy badacze Instagrama nazywają instagramersami wszystkich użytkowników posiadających konto w tej aplikacji. Czyni tak m.in. Lev Manovich w swojej książce Instagram and Contemporary Image (Manovich, 2017) czy Elisa Serafinelli w książce Digital Life on Instagram. New Social Communiacation of Photography, która stosuje oba nazewnictwa wymiennie, określając w ten sposób społeczność Instagrama, włączając w to społeczność igersów (Serafinelli, 2018, s. 88). Dlatego w poniższym artykule terminy Igers (igersi) i Instagramers (instagramersi) zostaną rozróżnione, aby uniknąć problemów znaczeniowych. Pojęcie igersów oznaczać będzie użytkowników Instagrama, tworzących oddolną, niepowołaną przez Instagram społeczność fanów fotografii mobilnej i tej aplikacji, używających do oznaczania swoich zdjęć hashtagów o strukturze \#igers_lokalizacja, uczestniczących w eventach przygotowywanych dla tej grupy i określających się mianem igersów. Mimo że w logo tej społeczności widnieje termin Instagramers, znacznie popularniejszy stał się skrót tego terminu - Igers który został niejako wymuszony przez Instagram, dlatego też w tym artykule to on będzie wykorzystywany do określenia tej społeczności. Natomiast termin Instagramers będzie oznaczać użytkowników Instagrama, którzy nie są skupieni wokół społeczności igersów, jednak angażują się w działalność na Instagramie i publikują zdjęcia, które za Manovichem można określić mianem casual (Manovich, 2017, s. 24-52). Przy takim zdefiniowaniu pojęć igersi, jak i instagramersi nie są tą samą grupą użytkowników Instagrama, co uzasadnia wprowadzone rozróżnienia. Warto zaznaczyć, że w języku polskim nie funkcjonuje termin określający użytkowników Instagrama. Można by ich nazwać instagramowiczami 
i wyróżnić wśród nich instagramersów. Jednak można tu przyjąć terminologię ustanowioną przez Manovicha, który analizuje rodzaje użytkowników i publikowane przez nich zdjęcia. Nie wspomina on jednak w swoich opracowaniach o społeczności igersów, a kładzie nacisk na wizualność zdjęć przedstawionych na Instagramie i kategoryzowanie ich, a użytkowników tej aplikacji nazywa instagramersami i ta terminologia zostanie przyjęta dla określania ogólnej grupy użytkowników Instagrama.

Pierwsze społeczności igersów powstały w 2011 roku, a dzisiaj funkcjonują w wielu krajach, takich jak Australia, Wielka Brytania czy Francja, jednak do tej pory nie powstała jeszcze żadna publikacja kompleksowo opisująca ich działalność. Choć o ich działaniach pisała Serafinelli i w swoich publikacjach prezentuje różne społeczności skupione wokół Instagrama, to igersi są tylko jedną z nich. Wydaje się, że o ile na temat Facebooka powstało już wiele publikacji, o tyle Instagram zaczyna być dopiero analizowany przez naukowców. Ta aplikacja staje się także istotna pod względem marketingowym, gdyż Instagram pozwala na różne, kreatywne wykorzystanie jego funkcji do działań reklamowych. Nastąpiło to zwłaszcza od momentu przejęcia tej aplikacji przez Facebooka ${ }^{1}$.

Metodą pozwalającą na zrozumienie fenomenu działalności społeczności igersów była analiza profili lokalnych grup, blogów prowadzonych przez tę społeczność, a także aktywne uczestnictwo w działaniach tych grup. Sporą pomocą były także informacje uzyskane od założyciela igersów Pilipa Gonzalesa, a także Glorii Zienciny-Kawuli, community managera@igerskraków. Pomocne okazały się również publikacje Manovicha ukazujące specyfikę użytkowników Instagrama, opracowania Serafinelli, która opisuje różne społeczności i działalności użytkowników Instagrama, kładąc nacisk na grupy skupiające wokół siebie społeczność, a także analiza treści publikowanych na blogach i w serwisach internetowych, które podejmowały tę tematykę.

Igersi to ludzie skupieni wokół Instagrama, którzy są miłośnikami fotografii mobilnej i przede wszystkim fotografują to, co ich otacza, czyli przestrzeń miejską, którą zamieszkują. Jest to grupa ludzi w różnym wieku i o różnej pozycji społecznej. Łączy ich natomiast pasja do robienia zdjęć. Głównie za sprawą fotografii mobilnej uwieczniają na zdjęciach miasto i życie w nim. Aby zostać igersem, wystarczy tylko użyć odpowiedniego hashtagu o konstrukcji \#igers_lokalizacja. Jednak ta społeczność nie powstałaby, gdyby nie aplikacja mobilna.

1 Facebook odkupił Instagrama w 2012 roku. Od tego czasu Instagram otrzymał sporo nowych funkcji, doszło do wielu zmian w aplikacji - zmieniono chronologiczne wyświetlanie w news feed, dodano InstaStories, wprowadzono możliwość publikowania reklam i postów sponsorowanych. 
Instagram to jedna $\mathrm{z}$ najpopularniejszych aplikacji mobilnych, założona w 2010 roku przez Kevina Systorma i Mike’a Kriegera. Zadebiutowała 5 października, początkowo tylko dla użytkowników iOS i już pierwszego dnia zarejestrowało się w niej 25 tysięcy osób (Instagram Launches). Obecnie na Instagramie funkcjonuje ponad miliard aktywnych kont, które mają zarówno charakter prywatny, jak i biznesowy (Datareportal.com, 2020). Jest to aplikacja, która opiera się na komunikacji wizualnej, której celem jest przeniesienie fotografii na „inny wymiar, aby robienie zdjęć mobilnych było szybkie, proste i piękne" (Welcome to Instagram, 2018). W pierwotnym założeniu aplikacja ta miała być prosta w użyciu, pobudzać kreatywność użytkowników i utrwalać codzienne chwile (Introducing Your Instagram Feed on the Web, 2018). W ciągu lat nie uniknęła zmian. Zostały dodawane różne funkcje, jednak jej niezmiennym elementem pozostało publikowanie zdjęć w celu dzielenia się nimi z innymi użytkownikami. Z sukcesem zaczęła integrować ludzi z różnych krajów, ułatwiając poznawanie nieznanych miejsc na całym świecie, a dodatkowo umożliwiając użytkownikom bycie fotografem (choć amatorem). Można w ten sposób mówić o pewnym fenomenie, bowiem aparat w smartfonie sprawił, że każdy jego posiadacz ma możliwość wykonywania dużej liczby zdjęć dobrej jakości. Dodatkowo dzielenie się nimi i docieranie do odbiorców nie jest trudne dzięki użyciu wbudowanej, prostej w obsłudze aplikacji, dającej możliwość edycji i nakładania filtrów. Aplikacja jednak nie ma takich możliwości, by budować społeczność, jak chociażby Facebook, w którym można założyć grupę i komunikować się z nią za pomocą postów, do których każdy członek grupy będzie miał dostęp. Mimo tych różnic na Instagramie powstało wiele społeczności fotografów, w tym igersi, których relacje społeczne kształtują się głównie przez elementy wizualne (w tym przypadku fotografie) i na podstawie konkretnych tematów (Serafinelli, 2017; Villi, 2015).

Założycielem igersów jest Phil Gonzales. O Instagramie dowiedział się parę tygodni po jego debiucie. Posiadał już wówczas pewną wiedzę na temat social mediów i zdecydował się ją wykorzystać. W styczniu 2011 roku, czyli niecałe cztery miesiące po uruchomieniu Instagrama, rozpoczął projekt, którego celem była próba pomocy ludziom w dzieleniu się pomysłami, a dodatkowo nawiązywaniu kontaktów przez Internet, opierając się właśnie na Instagramie. Gonzales założył bloga pod adresem instagramers.com, na którym udostępniał tutoriale, newsy i wywiady związane z Instagramem, by następnie zacząć tworzyć lokalne społeczności, które skupiały się na organizowaniu działań dla fanów tego medium (Gonzalez, 2018). Co istotne, był to oddolny projekt Gonzalesa, w żaden sposób niewspierany przez Instagram, a niekiedy społeczność ta utożsamiana jest bezpośrednio z tą aplikacją. Jak wspomina Gloria Ziencina-Kawula, 
community manager IgersKraków, w wywiadzie udzielonym portalowi happycontent.pl: „Jest to pierwsza społeczność założona wokół aplikacji mobilnej oddolnie, przez jej użytkowników i powstała z potrzeby poznania się i spotkania z innymi użytkownikami” (Stawarz-García, 2017). Aplikacja skłoniła ludzi do integrowania się (nie tylko wirtualnie) i wymieniania doświadczeniami związanymi z fotografią mobilną, a także z aplikacją, która temu służy.

Gonzales początkowo użył nazwy Instagramers zarówno na swoim blogu, jak i na profilu na Instagramie. Okazało się jednak, że Instagram nie pozwala na używanie nazw podobnych do słowa „Instagram”, dlatego pracownicy odpowiedzialni za funkcjonowanie profili w aplikacji zablokowali konto Gonzalesa pod nazwą @instagramers. W związku z tym w lutym 2011 roku Gonzales ponownie założył profil na Instagramie, ale tym razem pod nazwą @igers (Instagram Igers, 2018). Ta nazwa przyjęła się i stała się bazą dla tworzenia lokalnych profili i hashtagów. Pierwsza z grup igersów powstała w Madrycie i tam odbyło się pierwsze spotkanie fanów Instagrama. Bardzo szybko zaczęły też powstawać lokalne grupy tej społeczności w innych krajach, nie tylko w Hiszpanii. Dzięki temu, że Instagram gromadził coraz większą rzeszę fanów, społeczności zaczęły się coraz szybciej rozprzestrzeniać i po roku od założenia pierwszej z nich można było wyróżnić około 270 lokalnych grup, które aktywizowały fanów Instagrama (Gonzales, 2018).

Lokalnymi profilami igersów zarządzają managerowie (community managers). Są to osoby, które z własnej inicjatywy zakładają lokalną społeczność i nią kierują, nie otrzymując za to wynagrodzenia finansowego. Zazwyczaj są to dwie, trzy osoby, które prowadzą dany profil lokalny na Instagramie. Do ich zadań należy: budowanie i integracja społeczności w obrębie lokalnej grupy, wybór zdjęć, które w swoim opisie mają odpowiedni hashtag bądź zostały oznaczone poprzez funkcję „oznacz znajomych”, uzyskanie zgody autora zdjęcia na opublikowanie go na profilu lokalnej społeczności igersów, wszelkie kwestie techniczne związane z prowadzeniem lokalnych grup, organizowanie spotkań, takich jak InstaMeet czy PhotoWalk (Stawarz-García, 2017).

InstaMeet to spotkanie danej społeczności w wyznaczonym miejscu (Serafinelli, 2015, s. 104) - bardzo często są to różnego rodzaju instytucje, obiekty architektoniczne czy pustostany. W dużej mierze to od community managerów zależy, z jaką instytucją uda im się nawiązać kontakt. Jeśli uzyskają zgodę, wybrana grupa igersów ${ }^{2}$ ma dostęp do miejsc, do których wstęp jest ograniczony. Igersi podczas takich spotkań mają możliwość

2 Obowiązkowe są zapisy, ponieważ bardzo często ze względu na specyfikę miejsca w InstaMeet może brać udział ograniczona liczba uczestników. 
fotografowania wszystkiego, a ich zdjęcia publikowane na Instagramie są oznaczone dodatkowym hashtagiem np. \#operainstameet, co powoduje powstanie na Instagramie galerii zdjęć wszystkich użytkowników, którzy uczestniczyli w tym InstaMeet. To, jak często organizowane są takie spotkania, zależy w dużej mierze od community managerów i danej społeczności. Zazwyczaj odbywają się raz na dwa, trzy miesiące.

W terminie ustalonym odgórnie, zazwyczaj na wiosnę i jesień odbywa się Worldwide InstaMeet (WWIM). Wtedy wszystkie grupy igersów spotykają się w wyznaczonych miejscach, które następnie fotografują. WWIM przyjmują podobną formę do InstaMeet, jednak są to spotkania organizowane na całym świecie w tym samym terminie. WWIM mogą stanowić pretekst dla użytkowników, aby odbyć podróż do innego miejsca na świecie, by poznać społeczność igersów z innego kraju, wymienić się doświadczeniami i przede wszystkim by móc fotografować. Pierwszy z ogólnoświatowych InstaMeet odbył się 24 marca 2011 roku i był wspierany przez Instagram na ich oficjalnym blogu przez wyjaśnienie w krótkim poście, na czym polega InstaMeet i co należy zrobić, aby wziąć w nim udział (Worldwide InstaMeet, 2011).

PhotoWalks opierają się na podobnej zasadzie jak InstaMeet, lecz polegają na wspólnym spacerze członków społeczności np. po danej dzielnicy miasta i fotografowaniu. To, co jest jednak istotne zarówno podczas PhotoWalk, jak i InstaMeet, to odmienne spojrzenie na dane miejsce igersi podczas tych wydarzeń fotografują z różnej perspektywy te same obiekty i przestrzenie, ukazując różne podejścia do kompozycji i fotografii w ogóle.

Przynależność do którejś z lokalnych grup nie wyklucza możliwości brania udziału w eventach organizowanych przez inną lokalną społeczność. Organizowane są także różne inne akcje czy wydarzenia, jak wernisaże czy pikniki, które są uzależnione od kreatywności i zaangażowania danej grupy oraz community managerów.

Odrębną kwestią, jednak niezwykle istotną w przypadku igersów, jest korzystanie $\mathrm{z}$ hashtagów, które są trzonem funkcjonowania tej społeczności. Zostały one wprowadzone do Instagrama w styczniu 2011 roku, aby ułatwić wyszukiwanie zdjęć innych osób, które są podobne tematycznie i przedstawiają te same elementy (About Instagram, 2018). Użytkownicy oznaczając fotografię danym słowem kluczem, wysyłają swoje zdjęcie do odpowiedniego archiwum na Instagramie, w którym skatalogowane są wszystkie prace oznaczone tym znacznikiem (Thornton, 2014, s. 73). Od momentu wprowadzenia hashtagów instagramersi mogą wyszukiwać różnorodne i ciekawe zdjęcia i oglądać całe galerie fotografii w niezwykle łatwy sposób, co wcześniej nie było możliwe. Także community managerowie lokalnych grup w ten sposób wyszukują zdjęcia i je repostują, 
bowiem właśnie na hashtagach opiera się działalność igersów. Do tej pory pojawiło się ponad 500 milionów zdjęć oznaczonych takimi hashtagami, jak na przykład \#igers, \#igersmadrid, \#igerspoland itd. ${ }^{3}$ Gdyby jednak przyjrzeć się galerii zdjęć pod którymkolwiek z hashtagów nawiązujących do igersów, można łatwo zauważyć, że oznaczone zostały nim różnorodne zdjęcia, które w znaczny sposób różnią się od tego, co community managerowie wybierają (zatem polecają) do lokalnych galerii zdjęć. Dzieje się tak z jednej strony dlatego, że wielu korzystających z hashtaga chce, aby jego zdjęcie zostało zauważone i zrepostowane przez dany profil igersów, z drugiej zaś strony chodzi o zwiększenie zasięgu poprzez wybór popularnego oznaczenia. Tagując dane zdjęcie za pomocą hashtagu, np. \#igerspoland, osoby przeglądające galerię zobaczą takie zdjęcie i być może polubią, na czym zależy większości użytkowników Instagrama. A hashtag \#igerspoland już po latach użytkowania stał się bardzo popularny i potrafi generować duże zasięgi oglądalności.

W Polsce również funkcjonuje społeczność igersów. Profil @igerspoland został założony przez Pawła Ratajczaka z Poznania 17 czerwca 2011 roku - niecałe sześć miesięcy po rozpoczęciu projektu przez Philipa Gonzalesa. Pierwsze zdjęcie na profilu przedstawiało ówczesne logo igersów, które zostało zestawione z godłami Polski (Instagram IgersPoland, 2018b). Przeglądając pierwsze zdjęcia na Instagramie polskiej społeczności, zauważyć można, że profil @igerspoland nie angażował użytkowników, a publikacje pojawiały się sporadycznie. Dopiero w 2014 roku profil zaczął być prowadzony konsekwentnie, a zdjęcia innych użytkowników repostowane. Informowano o InstaMeet. Profil ten zaczął ewoluować i przyjmować inną niż dotychczas formę. Wtedy też do Pawła Ratajczaka dołączył Jarosław Marciuk (IgersPoland, 2018). W tym czasie istniały już lokalne profile takie jak@igerswroclaw czy@igersgdansk, które aktywizowały społeczność igersów w swoich miastach. Pierwszą lokalną grupą w Polsce był@igersgdansk, który powstał w listopadzie 2011 roku (Instagram IgersGdańsk, 2018). Obecnie w Polsce funkcjonuje ponad 25 lokalnych społeczności, skupionych zarówno w dużych miastach, jak i mniejszych miejscowościach. W ramach lokalnych grup organizowane są InstaMeets, PhotoWalks, wystawy czy spotkania, podczas których dana społeczność może się zebrać, porozmawiać o fotografii mobilnej i lepiej się poznać. Można to zaobserwować u@igerswroclaw, który organizuje \#instaczwartki.

$\mathrm{Na}$ stronie igerspoland.pl można przeczytać krótką historię igersów, dowiedzieć się, w których miastach w Polsce działają lokalne grupy oraz

3 Dane na podstawie korespondencji mailowej z Philipem Gonzalesem z dnia 20 marca 2018 roku. 
kto odpowiada za dane społeczności. Dostępne jest również kalendarium z listą wydarzeń i atrakcji przewidzianych dla fanów fotografii mobilnej. Sporadycznie prowadzony jest również blog współtworzony przez osoby zarządzające lokalnymi społecznościami, na którym można przeczytać porady dotyczące aplikacji (IgersPoland Blog) czy relacje z InstaMeet. Jednym z ciekawszych wpisów jest ten z WorldWide InstaMeet w Gdańsku z 2013 roku, w którym uczestniczył założyciel igersów, Phil Gonzales (Marciuk, 2017).

Polska społeczność igersów rozwija się bardzo dynamicznie. Profil @igerspoland na Instagramie ma ponad 24 tys. obserwujących ${ }^{4}$. Od sierpnia 2016 roku lokalne społeczności igersów są uwzględniane w statystykach Sotrendera (Wieczorek, 2016), który zajmuje się monitorowaniem mediów i co miesiąc przedstawia raporty, w tym Instagram Trends, gdzie zestawione są dane z najpopularniejszych kont na Instagramie i zaangażowania fanów. Polskie społeczności organizują różne tematyczne akcje, profil@igerspoland publikuje codziennie „zdjęcie dnia”, a raz w tygodniu wybierane jest „zdjęcie tygodnia” na podstawie największej liczby polubień. Organizowane są również wyzwania fotograficzne. Na podobnej zasadzie funkcjonują profile lokalne, jednak community managerowie wychodzą także z własnymi inicjatywami, w które chętnie angażują się użytkownicy, jak chociażby ustalanie tematyki zdjęć.

Odrębną kwestią pozostaje to, jakie zdjęcia publikują igersi. Manovich podzielił użytkowników Instagrama i publikowane przez nich zdjęcia na trzy kategorie: casual, professional i designed (zob. Manovich, 2017, s. 24-70). Kategoria casual dotyczy osób, które publikują na Instagramie zdjęcia siebie, tego, co robią czy gdzie bywają, chcąc dzielić się tymi chwilami uwiecznionymi na zdjęciach ze znajomymi. Osoby publikujące takie zdjęcia raczej nie dbają o estetykę zdjęć i ograniczają się do edycji zdjęć w ramach funkcji Instagrama. Są to zdjęcia najbardziej amatorskie, nastawione na wyrażanie emocji, w których nie liczy się kadrowanie, oświetlenie i kompozycja. Można uznać, że to głównie dla wykonujących takie zdjęcia powstał Instagram, dla którego celem nadrzędnym jest komunikacja wizualna oraz emocjonalne wzmacnianie więzi między użytkownikami. Pokazywanie, że jest się tu i teraz, a nadawca i odbiorca obrazu mogą doświadczyć tego samego obrazu niemal w tym samym momencie, zwłaszcza od momentu w którym Instagram wprowadził funkcję InstaStories (Villi, 2015, s. 8).

Kolejną kategorią są zdjęcia, które Manovich nazwał professional. Są one publikowane przez profesjonalnych fotografów i stanowią dla nich źródło zarobku. Ostatnia kategoria zdjęć, którą wyróżnia Manovich

4 Dane na dzień 20.06.2020 roku. 
nosi miano designed. Te zdjęcia są najbardziej dopracowane pod względem estetycznym, a ich kompozycja jest starannie zaplanowana. Według Manovicha te dwie ostatnie kategorie są najbardziej kontrolowane przez autora zdjęcia - pod względem kadru, koloru, oświetlenia. Oprócz tego Manovich zauważa, że w pewnym momencie, gdy Instagram zaczął przyciągać reklamodawców i coraz więcej użytkowników, zaczęli oni dbać o spójność stylu, estetyki i narracji w publikowanych przez siebie zdjęciach (Manovich, 2016).

Igersi publikują zdjęcia, które zakwalifikować można do każdej z tych kategorii. Zdarzają się oryginalne zdjęcia na profilach, które są typowymi profilami casual wyróżniającymi się ciekawym ujęciem, a oznaczone odpowiednim hasztagiem $\mathrm{z}$ powodzeniem mogą konkurować ze zdjęciami profesjonalistów. Z kolei profesjonaliści na swoich profilach nie publikują tylko fotografii mobilnych, ale także takie zdjęcia, które są bardzo dopracowane pod względem kompozycji, specjalnie pozowane, aby uchwycić ciekawy efekt wizualny, dbając o spójność i estetykę w swoim przekazie. W zasadzie nie ma znaczenia to, w jaki sposób ani przez kogo fotografia została wykonana, bowiem liczy się efekt końcowy, niecodzienne podejście do tematu i ciekawe kadrowanie. Mniej istotne jest także to, jakim aparatem w smartfonie zostanie zrobione zdjęcie, gdyż można je dopracować za pomocą kadrowania i oświetlenia, a także późniejszej obróbki i filtrów. Zdjęcie nie musi być wykonane tylko i wyłącznie smartfonem, bowiem zdarzają się również zdjęcia zrobione za pomocą aparatu cyfrowego bądź z wykorzystaniem drona.

Według badań m.in. Manovicha to, w jaki sposób, a także co instagramersi publikują na swoich profilach, jest zależne od szerokości geograficznej. To, w jakiej części świata żyjemy, ma wpływ na to, jakich używamy filtrów, jaka jest kolorystyka tych zdjęć i co najchętniej fotografujemy (Redi, Crockett, Manovich i Osindero, 2016). Kultura fotograficzna, w jakiej żyjemy, ma istotny wpływ na to, jak postrzegamy fotografię, jednak gdy przyjrzymy się różnym profilom lokalnych igersów, można dostrzec, że zdjęcia publikowane na lokalnych profilach są różnorodne zarówno pod względem obiektów fotografowanych (choć są to głównie fotografie, które określilibyśmy mianem street photo, czy urban photography - przedstawiające życie miasta), jak i pod względem kolorystycznym, estetycznym oraz sposobu kadrowania. To, co jednak jest podkreślane przez wiele osób, najbardziej inspirujące w tej społeczności jest różnorodne podejście do obiektów fotografowanych (Stawarz-García, 2017). Każdy ma inne spojrzenie na obiekt, który fotografuje, każdy co innego chce uchwycić, mimo że przedmiot fotografii bardzo często jest taki sam.

Społeczność igersów integruje w mocny sposób miłośników fotografii mobilnej. Członkowie tej społeczności działają nie tylko na Instagramie. Aby 
ułatwić kontakt między sobą, zakładają również grupy na Facebooku, w których wymieniają się uwagami na temat fotografii, nowych możliwościach Instagrama czy ciekawych eventów fotograficznych, w których użytkownicy mogą wziąć udział. Igersi wychodzą także poza swoje „mobilne galerie”, organizując wystawy zdjęć. Tak było m.in.w przypadku@igerskrakow, które we współpracy z hotelem Novotel po InstaMeet zorganizowało w nim ekspozycję zdjęć. Każdy mógł zgłosić swoje fotografie zarówno te z InstaMeet, jak $\mathrm{i}$ inne wykonane przez siebie zdjęcia, a najciekawsze, wybrane przez community managerów, zostały wydrukowane i przedstawione w hotelu w formie tradycyjnej wystawy (Instagram IgersKraków, 2018).

Igersi tworzą także w pewien sposób lokalną historię. Przykładem jest projekt, który został zrealizowany w Johannesburgu. Jego ideą było obserwowanie życia miasta i tego, jak się ono zmienia w czasie jednego roku oraz uwiecznianie tych zmian na fotografii, w wyniku czego powstawała książka Joburg (Igerbook, 2018). Killy Bacela - szef marketingu konsumenckiego i handlowego w Liberty Individual Arrangements, firmy, która jest sponsorem książki, stwierdził, że Johannesburg oczami igersa opowiada autentyczną południowoafrykańską historię (Edwardes, 2016). Dodatkowo pieniądze uzyskane ze sprzedaży książki zostały przekazane na rzecz Important Birds and Biodiversity Areas - organizację zajmującą się ochroną przyrody, głównie ptaków oraz zrównoważonym wykorzystaniem zasobów naturalnych.

Przeglądając zawartość innych profili igersów, możemy ujrzeć historię wielu miast, która tworzy się wraz z kolejnymi zdjęciami. Igersi podejmują także społeczne inicjatywy. Profil @igerswarsaw zorganizował akcję \#igerswarsaw_44, która miała nawiązywać do powstania warszawskiego (Instagram IgersPoland, 2018a), zaś @igerssydney zaangażował się w akcję społeczną, organizowaną przez Herd of Hope która miała na obszarach wiejskich podnieść świadomość przekazywania narządów. Był to nietypowy InstaMeet, jednak jak napisali community managerowie na Instagramie społeczności, był niezwykle ważny i poruszający (IgersSydney, 2018). Te działania pokazują, że igersi wychodząc ponad fotografię mobilną i ich zainteresowania, potrafią także zaangażować się społecznie. Czynia to pod hasłem community first, czego wyrazem w Polsce jest akcja \#życiedlaAlicji i zbiórka pieniędzy na leczenie dla żony Jarosława Maciuka, community managera @IgersPoland (IgersPoland Blog, 2020).

Warto dodać, że społeczność igersów wpływa również na kwestie marketingowe i PR-owe. Współpraca z różnymi instytucjami czy firmami gwarantuje jednostkom partnerskim z jednej strony ciekawe i różnorodne zdjęcia, z drugiej strony wpływa na PR tych instytucji. Wykorzystanie nazwy instytucji i tagowanie zdjęć odpowiednim hashtagiem oddziaływuje pozytywnie na wizerunek danej organizacji, a instytucja 
udostępniając swoje przestrzenie igersom, nie przeznacza na to dodatkowych funduszy. W związku z tym za pomocą niewielkich środków partnerzy zyskują na tych działaniach i zdobywają również ciekawe fotografie, które bardzo często mogą wykorzystać do promowania siebie. Między innymi Centrum Kongresowe ICE Kraków dzięki udostępnieniu igersom swojej przestrzeni na ich pierwszy oficjalny InstaMeet zajęło II miejsce w konkursie skierowanym do branży PR-owej „Złote Spinacze” w kategorii PR miejsca, miasta lub regionu (Stawarz-García, 2017).

Podobnie jest z kwestią wizerunku miast, bowiem i w tym względzie działania igersów mogą mieć pozytywny oddźwięk, zwłaszcza jeśli są to miasta o dużym potencjale turystycznym - chociaż w tym przypadku niekoniecznie dotyczy to działań całej społeczności, a raczej pojedynczych osób, które fotografują miasto. Na zdjęciach igersów bardzo często są przedstawiane różne jego części, co może skłaniać innych do odwiedzenia tych lokalizacji. Interesujące jest również to, że igersi starają się nawiązywać kontakty z innymi lokalnymi grupami, by umówić się na wspólne zwiedzanie i fotografowanie (Stawarz-García, 2017). Wymienianie się ciekawymi lokalizacjami do sfotografowania, a tym samym poznanie nowych ludzi, zawieranie nowych relacji sprawia, że fotografia staje się „łamaczem lodów” w poznaniu innych, a także elementem wiążącym społeczność (Serafinelli, 2017, s. 91-101).

Oddolny projekt Philipa Gonzalesa, który pierwotnie miał służyć skupieniu pewnej grupy osób wokół aplikacji mobilnej, jaką jest Instagram, i fotografii za pomocą smartfonu, doprowadził do powstania licznych grup lokalnych igersów na całym świecie. Chcąc należeć do tej społeczności, wystarczy użyć odpowiedniego hashtagu do oznaczania swojego zdjęcia z danego miasta. Manovich napisał, że Instagram nie tworzy pojedynczej kultury użytkowania, ale tworzy ich wiele (2017, s. 17). Jedną z nich są właśnie igersi, którzy formują grupę miłośników fotografii mobilnej i Instagrama, fotografują głównie miasto, w którym żyją, ukazując je z różnych perspektyw, bardzo często przez pryzmat swojego życia. Jak wspomniano, z czasem projekt zapoczątkowany przez Gonzalesa stał się niezwykle popularny. Opisując go, można użyć terminu Jenkinsa „kultura konwergencji” (Jenkins, 2007, s. VII-IX). Igersów można uznać za społeczność fanowską wchodzącą w interakcje społeczne, produkującą elementy kulturowe w postaci fotografii i utrwalającą zmieniające się miasto. Użytkownicy tej grupy w dużej mierze decydują o tym, w jaką stronę ona zmierza, narzucają sposób fotografowania i to co jest przedstawiane (Jen- $^{5}$ kins, Ford i Green, 2018, s. 34).

5 Henry Jenkins ukuł termin „kultura konwergencji” w celu opisania produkcji kulturowej $\mathrm{i}$ interakcji społecznych w ramach społeczności fanowskich. 
Należy dodać, że igersi zaczęli swoją działalność zaraz po powstaniu Instagrama i zapoczątkowali dzielenie się zdjęciami miasta. Owszem, istnieją profile na Instagramie, które funkcjonują w podobny sposób. W Polsce możemy wyróżnić chociażby stowarzyszenie Mobile Photo Trip, które też tworzy społeczność fanów fotografii mobilnej, a ich działalność opiera się na odwiedzaniu miast, które uczestnicy „Tripów” poznają wraz z jego gospodarzem - lokalnym fanem fotografii mobilnej (Mobile Photo Trip, 2020). Jednak ta grupa ma charakter lokalny, podczas gdy igersi funkcjonują na całym świecie. Natomiast inne profile o podobnym charakterze skupiają się bardziej na promowaniu lokalnych fotografów i repostowaniu ich zdjęć (np. profil @nowawarszawa)niż na tworzeniu społeczności nie tylko online, ale też offline i nie pełnią funkcji integracyjnej.

Serafinelli zauważa, że w społecznościach igersów spotkania nastawione są raczej na fotografowanie niż na poznawanie nowych osób (zob. Serafinelli, 2018, s. 95). Niemniej, patrząc na polskie społeczności, w niektórych przypadkach bardzo mocne zaangażowanie w tworzenie grup fotografów mobilnych, można uznać, że wszystko zależy od grupy osób i community managerów społeczności. Owszem, do integracji między uczestnikami, zwłaszcza offline, nie zawsze musi dochodzić, a bardziej będzie zauważalna integracja na Instagramie, gdzie kluczowe jest publikowanie dobrych zdjęć i chęć wyróżnienia się. Takie działania, zapośredniczone przez urządzenia mobilne, będą wystarczające do nawiązania relacji, ale już nie do jej podtrzymania, chociaż w niektórych przypadkach część społeczności igersów nawiąże między sobą trwalsze relacje także poza Instagramem (zob. Serafinelli, 2018, s. 97). Instagram okazuje się siecią społecznościową, która pozwala na kształtowanie relacji międzyludzkich głównie za pomocą elementów wizualnych. Społeczność igersów po blisko 10 latach istnienia wciąż funkcjonuje na całym świecie, angażując w swoje działania kolejnych fanów fotografii mobilnej, tworząc społeczności nie tylko w wirtualnym świecie, ale także poza nim. Wydaje się, że w związku z tym powinna ona stanowić pole do dalszych badań czy to w kontekście tworzenia i podtrzymywania społeczności komunikacji wizualnej, czy w aspekcie rozwoju fotografii mobilnej, która nabiera coraz większego znaczenia.

\section{Bibliografia}

About Instagram. (2018). Introducing Hashtags on Instagram. Pozyskano z: http://instagram.tumblr.com/post/8755963247/introducing-hashtags-on-instagram (dostęp: 25.03.2018).

Datareportal.com. (2020). Pozyskano z: https://datareportal.com/reports/ digital-2020-global-digital-overview (dostęp: 15.06.2020). 
Edwardes, R. (2016). Igers Become a Part of Local History. Pozyskano z: https:// citybuzz.co.za/65856/igers-become-a-part-of-local-history/ (dostęp: 15.03.2018).

Gonzalez, P. (2018). Featured: Meet @philgonzales. Pozyskano z: http://blog. instagram.com/post/18668039637/featured-meet-philgonzalez (dostęp: 15.03.2018).

IgerBook. (2018). Pozyskano z: https://igerbook.com/ (dostęp: 30.03.2018).

IgersPoland. (2018). Pozyskano z: http://igerspoland.pl/ (dostęp: 19.03.2018).

IgersPoland. (2019). Pozyskano z: http://igerspoland.pl/relacja-festiwal-fotografii-mobilnej-yes-im-mobile-we-wroclawiu-2019/ (dostęp: 1.06.2020).

IgersPoland Blog. (2018). Pozyskano z: http://igerspoland.pl/blog/ (dostęp: 19.03.2018).

IgersSydney. (2018). Pozyskano z: https://www.instagram.com/p/Bgf-355BiEj/?taken-by=igerssydney (dostęp: 26.03.2018).

Instagram Igers. (2018). Pozyskano z: https://www.instagram.com/p/BZ6uJ/ (dostęp: 15.03.2018).

Instagram IgersGdańsk. (2018). Pozyskano z: https://www.instagram.com/p/ SoYBC/ (dostęp: 26.03.2018).

Instagram IgersKraków. (2018). Pozyskano z: https:/www.instagram.com/p/ BVDNedyliUz/ (dostęp: 31.03.2018).

Instagram IgersPoland. (2018a). Igerswarsaw. Pozyskano z: https://www. instagram.com/p/rISUXNFFVq/? tagged=igerswarsaw_44 (dostęp: 26.03.2018).

Instagram IgersPoland. (2018b). Poland. Polska. Pozyskano z: https://www. instagram.com/p/F3uix/ (dostęp: 19.03.2018).

Instagram Launches. (2010). Pozyskano z: https://instagram-press.com/ blog/2010/10/06/instagram-launches-2/ (dostęp: 19.03.2018).

Instagram Press. (2018). Pozyskano z: https://instagram-press.com/our-story/ (dostęp: 25.03.2018).

Introducing Your Instagram Feed on the Web. (2018). Pozyskano z: http://instagram.tumblr.com/post/42363074191/instagramfeed (dostęp: 25.03. 2018).

Jenkins, H. (2007). Kultura konwergencji. Zderzenie starych i nowych mediów. Tłum. M. Bernatowicz i M. Filiciak. Warszawa: Wydawnictwa Akademickie i Profesjonalne.

Jenkins, H., Ford, S. i Green, J. (2018). Rozprzestrzenialne media. Tłum. M. Wróblewski. Łódź: Wydawnictwo Uniwersytetu Łódzkiego.

Manovich, L. (2016). Designing and Living Instagram Photography: Themes, Feeds, Sequences, Branding, Faces, Bodies. Pozyskano z: http://manovich.net/content/04-projects/097-designing-and-living-instagram-photography/instagram_book_part_4.pdf (dostęp: 1.06.2020).

Manovich, L. (2017). Instagram and Contemporary Image. Pozyskano z: http:// manovich.net/index.php/projects/instagram-and-contemporary-image (dostęp: 19.03.2018). 
Marciuk, J. (2017). Phil Gonzales w Gdańsku na WWIM13. Pozyskano z: http://igerspoland.pl/phil-gonzalez-w-gdansku-na-wwim13/ (dostęp: 25.03.2018).

Mobile Photo Trip. (2020). Pozyskano z: https:/www.facebook.com/pg/ MobilePhotoTrip/about/? ref=page_internal (dostęp: 21.06.2020)

Redi, M., Crockett, D., Manovich, L., Osindero, S. (2016). What Makes Photo Culture Different? Pozyskano z: http://manovich.net/index.php/projects/ what-makes-photo-cultures-different (dostęp: 26.03.2018).

Serafinelli, E. (2017). Analysis of Photo Sharing and Visual Social Relationships: Instagram as a Case Study. Pozyskano z: http://dx.doi.org/10.1080/1754076 3.2016.1258657 (dostęp: 13.02.2017).

Serafinelli, E. (2018). Digital Life on Instagram. New Social Communication of Photography. Bingley: Emerald Publishing Limited.

Stawarz-García, B. (2017). Gloria i stawa na Instagramie. Jak budować spoteczność igersów? Pozyskano z: http://happycontent.pl/gloria-i-slawa-na-instagramie-jak-budowac-spolecznosc-igersow/\# respond (dostęp: 15.03.2018).

Thornton, L.J. (2014). The Photo Is Live at Applifam: An Instagram Community Grapples With How Images Should Be Used. Pozyskano z: http://dx.doi. org/10.1080/15551393.2014.928147 (dostęp: 18.03.2015).

Villi M. (2015). "Hey, I'm here Right Now": Camera Phone Photographs and Mediated Presence. Pozyskano z: http://dx.doi.org/10.1080/17540763.2014 .968937 (dostęp: 12.08.2015).

Welcome to Instagram. (2018). Pozyskano z: http://instagram.tumblr.com/ post/8755272623/welcome-to-instagram (dostęp: 19.03.2018).

Wieczorek, M. (2016). Instagram Trends sierpień 2016: Moda, igersi $i$ urlopy. Pozyskano z: https://www.sotrender.com/blog/pl/2016/09/instagram-trends-sierpien-2016-moda-igersi-urlopy/ (dostęp: 25.03.2018).

Worldwide InstaMeet. (2011). 24 March 2011. Pozyskano z: http://instagram.tumblr.com/post/8756201749/worldwide-instameet-24-march-2011 (dostęp: 25.03.2018).

Klaudia Chwastek - uzyskała tytuł magistra w 2017 roku. Doktorantka Akademii Ignatianum w Krakowie. W kręgu jej zainteresowań znajdują się media społecznościowe i ich wpływ na społeczeństwo, w swoich badaniach zajmuje się przede wszystkim fotografią mobilną. 